\title{
WATER MINING AND EXTRACTIVISM OF THE SALAR DE ATACAMA, CHILE
}

\author{
INGRID GARCÉS ${ }^{1} \&$ GABRIEL ALVAREZ ${ }^{2}$ \\ ${ }^{1}$ Department of Chemical Engineering and Mineral Process, Universidad de Antofagasta, Chile \\ ${ }^{2}$ Department of Geomensura and Geomatics Engineering, Universidad de Antofagasta, Chile
}

\begin{abstract}
The sustainability of the lithium industry in Chile is being threatened by the series of environmental and social impacts occurring in the Salar de Atacama. This study is based on a review of technical and environmental reports, including the inspection processes carried out to date at the Salar de Atacama, the main lithium brine deposit worldwide. Demand for clean technologies has increased global lithium production, pressuring the production system to increase the quota of brine extraction to satisfy the greater demand for this resource. As a result of the extraction process in the salt flat, millions of tons of water are removed from the system in an arid region, the biota is affected, and natural conditions change in this fragile and dynamic ecosystem. The impact on the salt flat not only translates into loss of water, but also in the disappearance of vulnerable species that only exist in these places, the loss of the cultural heritage of indigenous peoples, the losses of millions of years of evolution of adaptation processes of species, including the extremophilic organisms. From the economic point of view, although both companies are committed to compensating the damage to the Atacameñas communities, one with $3.5 \%$ of the value of sales and the other with a contribution of US\$15 million annually, it is not comparable with the deterioration of the Salar and the loss of cultural heritage. In conclusion, it is verified that the lithium mining industry causes strong environmental and social impacts, so we cannot speak of lithium as a synonym for "green economics." Therefore, can the lithium industry be considered of strategic relevance to the development of zero carbon technologies?

Keywords: water mining, extraction of lithium, Salar de Atacama, socio-environmental impacts, natural brines, Andean biodiversity, salt flat, Andean evaporites.
\end{abstract}

\section{INTRODUCTION}

The Atacama Desert is one of the driest deserts on earth [1]-[4], what can average annual precipitation to reach $1 \mathrm{~mm}$ [5], which means long periods of extreme aridity, but another period can occur strong rainfall events. During in the summer months, in the "Invierno Altiplánico" (highlands winter), the rain that enters from the Amazon Basin towards the Andes mountain, produces great avenues of waters that drain into the east sector towards the Pacific ocean. The paleohydrological studies in Salar de Atacama have allowed verifying two periods of greater groundwater discharge [6]. The first period of 12,800 and 8,100 years $\mathrm{BP}$, registered only in the eastern part of the Salar de Atacama (Tilomonte), and a second period of greatest activity of 7,400 and 3,000 years BP registered in the area of Tilomonte, Loa river, Salado river and Quebrada Puripica [5], [7].

Regional fault systems NS and WE, has facilitated the formation of major geomorphological entities: Cordillera de la Costa, Intermediate Depression, Precordillera, Preandine Basins, Altiplano and Andean Cordillera, and local endorheic basins, together with geological, climatological and aridity factors In the northern region of Chile, the formation of continental evaporites has been favored, with rich chemical components, such as Li, Boron, Potassium, etc., product of the leaching of cenozoic volcanic rocks that surround these basins

Today, mainly the brine extraction option is used, versus minerals rocks principally by to be economically more profitable. In this study, we assessed the environmental impacts that to production over to extraction of brines for production of lithium carbonate $\left(\mathrm{Li}_{2} \mathrm{CO}_{3}\right)$ from 
the world leading producers SQM and Albemarle which are located at the Salar de Atacama in Chile. $\mathrm{Li}_{2} \mathrm{CO}_{3}$ is the main feed material for lithium-based products, e.g. batteries. Rechargeable lithium-ion (Li-ion) batteries are considered to be a better option to meet the future requirements of electric vehicles $(\mathrm{EV})$, which in turn are expected to play a major role in the transition towards a more sustainable mobility from the world.

\subsection{Lithium mining companies}

The Anaconda company discovered lithium in the brines of the Salar de Atacama in 1962. One of the large lithium-producing companies heard this news and studied the feasibility of the lithium project in Chile. This was possible due to adaptation of the Silver Peak, Nevada lithium extraction process by Foote Minerals (known today as Albemarle) in 1979. In 1980 the Sociedad Chilena de Litio Ltda (SChL) was formed, with Foote 55\% (American technology) and CORFO 45\% (contributions from the Chilean state), for production and sale of lithium compounded up to 200,000 MT of equivalent lithium. In $1984 \mathrm{SChL}$ started production of lithium carbonate with a capacity of 14 million lbs/year. In 1999 started producing lithium chloride. In 2016 Albemarle was authorized for expanded brine extraction capacity to $442 \mathrm{~L}$ per second, and to a production of 27,000 tons of lithium and 136,000 tons of potassium. At the next year modified the contract with CORFO, from 27,000 to 47,000 tons of lithium and from 136,000 to 218,000 tons of potassium salts, maintaining the extraction of brine at $442 \mathrm{~L}$ per second. In March 2018, Albemarle was authorized to increase the quota from 120,000 to 140,000 tons per year without further extraction of brine and water.

In 1986 a lease agreement is signed to produce 180,100 tons of lithium for 30 years with SQM (Chilean company). In 1997 started the production of lithium carbonate with an initial capacity of 17,500 t/a. SQM has an authorized brine consumption of 1,700 L per second and an annual production of 48,000 tons of lithium and 2,000,000 tons of potassium. The excess of brines are reinjected into the salt flat. In 2005 SQM started operations in its Lithium Hydroxide Plant with an annual capacity of 6000 tons. Between 2008-2011 SQM begins to expand the capacity of its lithium carbonate plant from 30,000 to 48,000 tons. The contract will end on December 31, 2030 [8], with the extraction of net lithium from the brines in 620,000 tons of LME and without considering reinjection

\section{STUDY AREA AND METHODOLOGY}

\subsection{Salar de Atacama}

The Salar de Atacama is located at the coordinates $23^{\circ} 30^{\prime}$ south and $68^{\prime} 15^{\prime}$ west, at 2,300 masl, in an endorheic basin. It is a pre-Andean salt flat and it is the third largest salt flat in the world. Its economic importance lies in the high concentrations of lithium $(1,500$ ppm on average and variations between 600 to $5,000 \mathrm{ppm}$ ) and potassium, besides, providing crucial ecosystem services to local communities and the diversity of flora and fauna species. The surface of the salt flat is approximately $2,770 \mathrm{~km}^{2}$, with brackish waters as a result of recharging the surface and underground channels that carry salts caused by the leaching of volcanic rocks [9]. The water bodies to arrives in the basin are rivers San Pedro (mean flow $0.8-1.2 \mathrm{~m}^{3} / \mathrm{s}$ ) and Vilama (mean flow $0.15-0.25 \mathrm{~m}^{3} / \mathrm{s}$ ) for the north side [10], freshwater and saline springs, for the east and south side. Besides, the salt flat receives important subterranean contributions of water, springs originated by the volcanic formations of the Andes. The dissolved components in the waters have two main origins: the alteration of volcanic rocks provides $\mathrm{K}, \mathrm{Li}, \mathrm{Mg}, \mathrm{B}$ and a low concentration of $\mathrm{Na}$ and $\mathrm{Ca}$, meanwhile the 
redissolution of antique salts (under volcanic formations) make an important contribution with $\mathrm{Na}, \mathrm{Cl}, \mathrm{Ca}$ and $\mathrm{SO}_{4}$ in the more saline waters [11].

In the Salar two zones are clearly differentiated: the saline nucleus and the marginal zone. The central nucleus of crystallized salts, of around $1,400 \mathrm{~km}^{2}$, is mainly made up of halite and clastic sediments [12]. This core is permeable in the first 30 to $40 \mathrm{~m}$ depth and its hydrogeological properties of transmissibility and storage are heterogeneous, with high permeability values (up to $0.03 \mathrm{~m} / \mathrm{s}$ ) and in other areas with predominantly clay characteristics (less than $110-6 \mathrm{~m} / \mathrm{s})$; while very low permeability strata $(110-6$ and 1 $10-8 \mathrm{~m} / \mathrm{s}$ ) have been detected at the edges of the nucleus [13]. Precipitation in the Salar is concentrated in the austral summer, and reaches up to $25 \mathrm{~mm} /$ year, potential evaporation is $2000 \mathrm{~mm} /$ year [11]. The thermal amplitude can exceed the 30 degrees and mean relative humidity is ca. $50 \%$, median wind speed reaches $10 \mathrm{~m} / \mathrm{s}$ at $0.4 \mathrm{~m}$ above the ground, and generally has a westerly direction [14].

The marginal zone is made up of two units, the silt zone and the efflorescence zone. The silt zone is located on the edges of the saline deposit, presenting an abundant and homogeneous vegetation. This area is made up of clays and silts of alluvial origin (chlorides and sulphates). The efflorescence zone is located between the silt zone and the saline nucleus, this area is mainly made up of gypsum, anhydrite, carbonate and borate salts [15], and presents a relatively abundant vegetation. Cornellà et al. [16], describes a strip around the lagoons (south of Barros Negros) on the eastern edge of the Salar, in which the lithological substrate is interspersed with sedimentary and evaporitic deposits, which shows the interrelation between both depositional environments.

The eastern edge of the Salar, known as the marginal zone (saline interface), is the most sensitive sector made up of a lagoon system and with the presence of vegas and peatlands, generated by the outcrop of freshwater contributions of underground origin that find a barrier or saline wedge [10]. The most relevant sectors include the Tilopozo valley system and the Peine lake system, with the La Punta and Salada lagoons in the southern sector. In the middle part of the marginal area are the lagunar system Soncor (with the Chaxas, Puilar and Barros Negros lagoons) and Aguas de Quelana. Finally, towards the northern sector are the Baltinache, Cejas and Tabinquiche lagoons. The west side of the salt flat does not have lagoon. The Sistema Soncor and Aguas de Quelana area is made up of permanent lagoons that sustain biological diversity and serve as an important nesting center for flamingos.

Inside the saline core, there are two private companies that extract lithium-rich brines, SQM and Albemarle. Several communities of indigenous peoples, workers from mining companies and a high percentage of tourists also live around the salar

\subsection{Extraction process in Salar de Atacama}

The brine is pumped from $35 \mathrm{~m}$ beneath the crust to evaporation ponds. These brine is concentrated by solar evaporation and wind from $0.18 \%$ Li y $2.5 \%$ en $\mathrm{K}$ to as $6 \%$ lithium, by means evaporation/precipitation steps. This technology involves several steps of successive evaporation of the original brine in different ponds with precipitation and harvesting of different salts (halite, silvinite, carnalite de K, bischoffite, carnalite de lithium) [17 ]-[20]. The evaporation/precipitation steps take up between 9 and 14 months from the beginning of the extraction process (brine pump out of the underground aquifers). The extraction process into brines naturally occur at high altitude and in desert areas [21], [22], solar/wind evaporation is a cost effective method for concentrating brines and precipitating salts [20].

The concentrated brine is transported at chemical Plant (outside to Salar), next to the city of Antofagasta, for treated with sodium carbonate (soda ash), thereby precipitating lithium 
carbonate. Chemical species that do not spontaneously precipitate in the ponds need to be removed by chemical treatment. Borates are usually removed by solvent extraction, while magnesium cations are removed by precipitation with lime. In case of lithium battery grade, the primary lithium carbonate is re-dissolved and reprecipitated to reach the purity needed.

\subsection{Methodology}

In this work we focus on evaluating the more significant environmental aspects (SEAs) over the Salar de Atacama a cause of extraction of the brines for production of lithium. We considerer impacts over natural resources: water, fauna, flora, and social-cultural. This study adopted a qualitative case study methodology [23]. Specifically, the case study methodology was used to explore the characterization and conceptualization of a mining space and the affected ecosystem. Case studies allow researchers to study a phenomenon and its environment in a natural environment and obtain valuable information on complex processes [24]. The data collection process consisted of to collets antecedents and analyzing the data from reports and articles in relation to mining sustainability, jointly conducting interviews with people living in the surroundings of the salar, conducting observations in the field, contrasting with aerospace images and photographs.

During the field campaigns, we visited the mining expansion area that included the mining operations of both companies that operate the salar. Scientific articles, reports from public institutions, reports from mining companies that are in the Environmental Assessment Service were reviewed, along with the testimonies of local actors from the region's indigenous communities. The main research questions were focused on the different social and environmental dimensions of lithium extraction and the impacts on communities.

\subsection{Results and analyses}

The analysis carried out in China, the mayor destination of lithium minerals and chemicals, reveals the growth of the electric vehicle (EV) market [25]. The studies confirm the dependence on lithium imports, so much so that the reserves and demand for lithium in China show an increasing increase [26]; lithium availability for EVs in the European Union will be only $0.5 \mathrm{Mt}$ by 2050 [27]. On the other hand, rechargeable batteries have had an explosive increase from $23 \%$ in 2008 to $65 \%$ in 2019 [28]. In this context, the competition for lithium in recent years to ensure its provision, have their sights set on the reserves of the South American salt flats, and especially on the Salar de Atacama. The companies that operate in the salar have increased the extraction of brines. Albemarle between 1984-2009 exploited an average annual brine flow of $142 \mathrm{l} / \mathrm{s}$, increasing to reach $442 \mathrm{l} / \mathrm{s}$ by 2020 , and ending at 600 1/s. The authorized freshwater rights is $23.5 \mathrm{l} / \mathrm{s}$. For its part, SQM between 1998-2006 extracted approximately $600 \mathrm{l} / \mathrm{s}$ of brines, in 2010 they pumped $1400 \mathrm{l} / \mathrm{s}$ and today they reach 1600 l/s, having authorized a maximum total exploitation flow of 1700 1/s [29]. The water rights granted and environmentally approved for SQM represent $6 \%$ of the total groundwater granted for extraction in the Salar de Atacama basin [30].

In addition to the foregoing, in the southern sector of the Salar there are freshwater withdrawals from the copper miners BHP and Minera Zaldívar, which have made efforts to increase their quota of 1815 and $625 \mathrm{l} / \mathrm{s}$, respectively. The newspaper and news reports show that the water levels in the Salar are the lowest, and the basin without precipitations has no possibility of recovery, even more so if the extraction of brines is increasing. Water-related conflicts mark the different communities in northern Chile [31]-[35]; Although these conflicts have occurred in general with the mining industry, specifically, it is the shortage of 
water that is the trigger, added to the scarce rainfall, the high rates of evaporation, global warming and the industrial quantity of extractions in the salt flat for purposes miners, have increased discontent in the population.

In the case of affectation to the Atacama Salt Flat, we make use of the audit reports for the years 2013, 2014, 2015 and 2016 of the Superintendency of the Environment, SMA. The commitment of non-affectation refers exclusively to the Soncor, Quelana Waters and Vegetation Systems of the Eastern border of the Salar, and is related to the brine and freshwater extraction activities. The results of the audits showed the affectation of water courses as a result of the exploitation of its brines [36]. The above shows the deterioration in the flora associated with wells and catchment sites [36]. In addition, there was a notable decrease in the water levels in the salt flat, added to the absence of reports of injection and reinjection during the 2012-2013 period. The inspection body verified the loss of 13 specimens of Algarrobo (Prosopis Flexuosa), corresponding to $22 \%$ of the specimens monitored [37]. The decrease of the water mirror of the lacustrine systems associated with the vegetative system of the Eastern border of the Salar was verified, especially in the Laguna Interna. This fact explains large sectors without vegetation and the increasing deterioration of the flora over time. Events that are repeated in the Pozo Camar with a number of species in the dry state and with an increase in the very weak category [38]. The progressive affectation of the state of vitality of the Algarrobos trees, calculation errors in the reinjection of brines, problems in updating the Contingency Plan for the Peine System, are some of the affectations found during the audit of the following year [39]. In the last 20 years of exploitation of the salar, there is a significant decrease in plant coverage in the Salar, fewer plant and floristic species are found in the eastern sector of the areas close to exploitation, the most sensitive area, where its deterioration has been faster. Recent studies with satellite images and spectroradiometry show the increase in the loss of vegetation in the Salar in the last 20 years as a result of the extraction of its brines [40], [41].

The lithium industry has expanded its operations territorially the last two decades increasing from 20.54 to $80.53 \mathrm{~km}^{2}$, that is, 4 times more than the scale of production in 1997 . The average expansion rate is $7.07 \%$ per year. The operational increase in the extraction of brines increases the consumption of water for their tasks. During the evaporation process the brines are concentrated approximately 30 times with respect to the initial lithium concentration, from $0.2 \%$ to $6 \%$ approx. To produce a ton of lithium, 2 million $\mathrm{L}$ of water are evaporated from the wells, that is, 2,000 tons of water that cannot be recirculated and thousands of tons of saline waste are generated [42]. Even when some mention that the brines are not water, the truth is that during the evaporative process what is lost from the system is water. During the process of concentration in pools, various discard salts result. The approximate volume of additional waste salts is $888,321 \mathrm{~m}^{3} /$ month at the MOP plant and $135,417 \mathrm{~m}^{3} /$ month at the SQM SOP plant [43]. In other words, $12,284,856 \mathrm{~m}^{3}$ of waste salts are deposited monthly, thereby increasing the area of waste salt storage in the core of the salt flat, constituting $37.9 \mathrm{~km}^{2}$ (MOP and SOP plants) [44]. The approximate composition of the waste salts is sodium chloride with traces of ions characteristic of the salt brine (potassium, calcium, magnesium, sulphate, chloride, lithium and boron) (personal communication during visit to the salt), with humidity lower than $10 \%$ and solids greater than $90 \%$. In the case of Albemarle, the amount of sodium chloride accumulated in cakes in the Salar reaches approx. 3.5 million tons, which with the increase in approved production will generate a total of close to 745,000 tons per year [13] in the next 10 years.

As for evaporation ponds, they have also increased, covering a total of 8.36 ha of evaporation surface [13] and in SQM they reach 1700 ha [44].This large extensions of evaporation pools cause ecocide of birds [45]. 
Based on a series of technical reports, the Ministry of Mining, through CORFO [46], published the consolidated report for the Salar de Atacama basin, in which in the natural regime, the entrances are similar to the exits, $6,810 \mathrm{l} / \mathrm{s}$ versus an interval between $6,575-6,975 \mathrm{l} / \mathrm{s}$, respectively. However, in a system influenced by anthropic extractions between the years 2000 to 2015, the outputs are greater than the inputs, ranging between $8,442 \mathrm{l} / \mathrm{s}$ and $8,842 \mathrm{l} / \mathrm{s}$ [46]. In other words, there is clearly an imbalance in the system. Between the years 2000 to 2015, there is an increase in the discharge of the salt flat and its recharge is maintained, so the decrease in the water balance is caused by extraction of brine and fresh water from the basin.

The impacts observed in the Atacama Salt Flat in relation to lithium mining in the salt flats are the same as in the Puna de Atacama (north-western Argentina) [47]. The lithium extraction inevitably harms the soil and also causes air contamination [48]. Indigenous communities have seen their water supplies diminished for their domestic activities, actually the regions have not the water, when in the past, the $40 \%$ of the total superficial discharge are estimated to be used by agriculture [49]. The salt flats where lithium is found are located in arid territories. In these places, access to water is key for the local communities and their livelihoods, as well as the local flora and fauna. In Chile's Atacama salt flats, mining consumes, contaminates and diverts scarce water resources away from local communities [31]. The extraction of lithium has caused water-related conflicts with different communities, such as the community of Toconao in the north of Chile [34]. In Argentina's Salar de Hombre Muerto, local communities claim that lithium operations have contaminated streams used for humans, livestock and crop irrigation [48]. Extraction of lithium inevitably damages the soil and also causes air pollution. In salt flats where lithium is found, they are arid territories. In these places, access to water is key for local communities and their livelihoods, as well as for local flora and fauna. Mining consumes, contaminate and diverts scarce water resources from local communities, causing water-related conflicts in different communities, such as in Toconao, Peine and other locations. At Olaroz-Caucharí Salt Flats in Argentina, local communities claim that lithium operations have contaminated streams used to agricult, livestock and crops [50]-[52].

SQM production costs are between USD 0.5 and USD 0.8 (the most inexpensive in the world for carbonate produced in brines), establishing an attractive average profit margin around USD 1.70 per pound produced (a very profitable figure given that the capacity of installed production is 40,000 tons per year) [53]. While the social costs of the communities by not having water, they lose their agriculture, livestock, they lose their traditional way of life and their culture. Finally, if we look at how much is reported to the Chilean state for operations in the Salar de Atacama, in 2015 SQM reported around USD 15.2 million, compared to the USD 223 million received by the company. For his part, Albemarle contributed USD 1.4 million, a very low figure considering that in 2015 the average price exceeded USD 5,300 per metric ton [54]. It is necessary to highlight that as a result of the social conflicts over the territories, both companies that extract lithium in the Salar de Atacama, managed to sign agreements in which one up to now supports a model of local development program with more conservative projects, under the Responsibility scheme. Social Business, and with a contribution to current prices of USD 15 million annually, while the other company signs a shared value agreement for $3.5 \%$ of sales of lithium and potassium [33], [55].

\section{CONCLUSION}

It is evident that the demand for lithium in the world show an increasing increase, therefore more availability is required to satisfy lithium consumption mainly in the EV segment, as 
part of the essential for decarbonizing mobility strategy. Lithium is currently extracted from concentrated brines in desertic ambient, heterogeneous, fragile ecosystems with a unique biodiversity.

The results show that the increase in the pumping rate as a product of the greater increase in its extraction, favors the depletion of water in the basin, as a result a saline system is presented that does not reach equilibrium (greater outputs than inputs). This is corroborated by studies of various sources and satellite images. As a consequence of the water deficit, from the results presented and analyzed in this work, it is clearly observed that in recent years, the Salar de Atacama ecosystem shows loss of vegetation and fauna, changes due to the decrease in water, a vital element for life, besides that as a result of these changes in environmental conditions the balance of microbial communities is altered with possible consequences at different trophic levels.

The process of extraction/concentration of brines through large extensions of evaporation pools, although economically profitable, operationally it is not efficient (it takes between 9-14 months), but environmentally it causes the ecocide of birds, especially flamingos that are misled by these large bodies of water, it also generates large amounts of salt product from the different salts precipitate sequentially.

The lithium industry is a water mining industry, which impacts the ancestral territories that have been culturally associated with the rituality of water and today are damaged in their agriculture and grazing, therefore, it is far from being considered an environmentally and socially sustainable industry. In light of the results presented, can the lithium industry be seen as synonymous with the green economy?

Finally, it is urgent to change the current extraction process for a more sustainable one, or to recover the huge amount of water lost by evaporation in a desert region.

\section{ACKNOWLEDGEMENT}

This work has been carried out within the framework of the Poorly Developed Areas Project of the Vice-Rectory for Research, Innovation and Postgraduate (VRIIP) of the University of Antofagasta.

\section{REFERENCES}

[1] Dunai, T.J., González López, G.A. \& Juez-Larré, J., Edad de aridez del oligocenomioceno en el desierto de Atacama revelada por la datación por exposición de los accidentes geográficos sensibles a la erosión. Geology, 33(4), pp. 321-324, 2005. DOI: 10.1130/G21184.1.

[2] Azua Bustos, A., González Silva, C. \& Corsini, G., The hyperarid core of the Atacama Desert, an extremely dry and carbon deprived habitat of potential interest for the field of carbon science. Frontiers in Microbiology, 8, p. 993, 2017. https://doi.org/10.3389/fmicb.2017.00993.

[3] Ruthsatz, A.D., Sarmiento Flores, A., Diaz, D., Salazar Reinoso, P., Herrera, C. \& Brasse, H., Joint TEM and MT aquifer study in the Atacama Desert, North Chile. Journal of Applied Geophysics. 153, pp. 7-16, 2018. https://doi.org/10.1016/j.jappgeo.2018.04.002.

[4] Voigt, C., Klipsch, S., Herwartz, D., Chong, G. \& Staubwasser. M., The spatial distribution of soluble salts in the surface soil of the Atacama Desert and their relationship to hyperaridity. Global and Planetary Change, 184, 2020.

[5] Herrera Lameli, C. \& Custodio, E., Origen de las aguas de pequeños manantiales ubicados en la costa norte de Chile, en las cercanías de Antofagasta. Geología Andina, 41(2), pp. 314-341, 2014. DOI: http://dx.doi.org/10.5027/andgeoV41n2-a03. 
[6] Rech, J., Quade, J. \& Hart, W., Isotopic evidence for the origin of Ca and S in soil gypsum, anhydrite, and calcite in the Atacama Desert, Chile. Geochimica et Cosmochimica Acta, 67(4), pp. 575-586, 2003.

[7] Herrera Lameli, C. et al., Groundwater origin and recharge in the hyperarid Cordillera de la Costa, Atacama Desert, northern Chile. Science of The Total Environment, 624, pp. 114-132, 2018. https://doi.org/10.1016/j.scitotenv.2017.12.134.

[8] CCHEN No 2287/2018, Acuerdo No 2287/2018. Autoriza a la empresa SQM Salar S.A., cuota de extracción de litio desde Salar de Atacama para procesar y vender. www.cchen.cl/transparencia/transparencia_2018/RespuestasSolicitudes/2018/Acto\% 20Adm.\%20AU0003T0000165.pdf. Accessed on: 3 May 2019.

[9] Risacher, F., Alonso, H. \& Salazar, C., Geoquímica de Aguas en Cuencas Cerradas: I, II y III Regiones - Chile. Vol. III: Estudio de Cuencas de la II Región. Convenio de Cooperación DGA - UCN - IRD. (S.I.T. N051), 1999.

[10] Salas, J. et al., Hydrogeology of the lacustrine system of the Eastern Margin of the Salar the Atacama (Chile). Boletín Geológico y Minero, 121(4), pp. 357-372, 2010.

[11] Risacher, F. \& Alonso, H., Geoquímica del Salar de Atacama, parte 2: Evolución de las aguas, Revista Geológica de Chile, 23(2), pp. 123-134, 1996.

https://doi.org/10.5027/andgeoV23n2-a02.

[12] Pavlovic, P., La industria del Litio en Chile, Ingenieros. Revista del Colegio de Ingenieros de Chile A.G. Edición N0209, pp. 32-37, 2014.

https://issuu.com/colegiodeingenieroschile/docs/revista_ingenieros_n_ 209.

Accessed on: 23 Oct. 2019.

[13] Modificaciones y Mejoramiento del Sistema de Pozas de Evaporación Solar en el Salar de Atacama Región de Antofagasta, Chile. www.e-seia.cl/archivos/ 20090514.182228.pdf. Accessed on: 13 Feb. 2020.

[14] Catastro General de usuarios de aguas de los cauces afluentes al Salar de Atacama, Informe final. Tomo 1-4, Dirección General de Aguas, Ministerio de Minería, 1991.

[15] Vásquez, C., Ortiz, C., Suárez, F. \& Muñoz, J.F., Modeling flow and reactive transport to explain mineral zoning in the Atacama salt flat aquifer, Chile. Journal of Hydrology, 490, pp. 114-125, 2013. https://doi.org/10.1016/j.jhydrol.2013.03.028.

[16] Cornellà, O. et al., Hidrogeología de los sistemas lagunares del margen E del Salar de Atacama, Actas XII Congreso Geológico Chileno, Facultad de Ciencias Físicas y Matemáticas, Universidad de Chile, 2009.

[17] An, J.W., Kang, D.J., Tran, K.T., Kim, M.J., Lim, T. \& Tran, T., Recovery of lithium from Uyuni salar brine. Hydrometallurgy, 117-118, pp. 64-70, 2012.

[18] Talens Peiró, L., Villalba Méndez, G. \& Ayres, R.U., Lithium: sources, production, uses and recovery outlook. JOM, 65(8), pp. 986-996, 2013.

[19] Swain, B., Recovery and recycling of lithium: A review. Separation and Purification Technology, 172, pp. 388-403, 2017.

[20] Flexer, V., Baspineiro, C.F. \& Galli, C.I., Lithium recovery from brines: A vital raw material for green energies with a potential environmental impact in its mining and processing. Science of the Total Environment, 639, pp. 1188-1204, 2018. https://doi.org/10.1016/j.scitotenv.2018.05.223.

[21] Munk, L.A., Hynek, S.A., Bradley, D., Boutt, D.F., Labay, K. \& Jochens, H., Lithium brines: A global perspective. Rev. Econ. Geol., 18, pp. 339-365, 2016.

DOI: $10.5382 /$ rev.18.14.

[22] Castino, F., Bookhagen, B. \& Strecker, M.R., Rainfall variability and trends of the past six decades (1950-2014) in the subtropical NW Argentine Andes. Climate Dynamics, 48, pp. 1049-1067, 2017. https://doi.org/10.1007/s00382-016-3127-2. 
[23] Yin, R.K., Case Study Research: Design and Methods, 4th ed., Sage Publications: Thousand Oaks, 2009.

[24] Yin, R.K., Case Study Research: Design and Methods, Sage Publications: Thousand Oaks, 1994.

[25] Hao, H., Liu, Z., Zhao, F., Geng, Y. \& Sarkis, J., Material flow analysis of lithium in China, Resources Policy, 51, pp. 100-106, 2017.

DOI: $10.1016 /$ j.resourpol.2016.12.005

[26] Zeng, X. \& Li, J., Implications for the carrying capacity of lithium reserve in China. Resources Conservation and Recycling, 80(1), pp. 58-63, 2013.

[27] Miedema, J. \& Moll, H., Lithium availability in the EU27 for battery-driven vehicles: The impact of recycling and substitution on the confrontation between supply and demand until 2050. Resources Policy, 38(2), pp. 204-211, 2013. https://doi.org/10.1016/j.resourpol.2013.01.001.

[28] Lithium. Mineral Commodity Summaries 2020. U.S. Geological Survey, Mineral Commodity Summaries, January 2020, pp. 98-99, 2020. https://pubs.usgs.gov/ periodicals/mcs2020/mcs2020-lithium.pdf. Accessed on: 15 May 2020.

[29] Línea de Base EIA Modificaciones y Mejoramiento del Sistema de Pozas de Evaporación Solar en el Salar de Atacama, Sociedad Chilena de Litio Ltda; Gestión Ambiental Consultores, 2009. http://bibliotecadigital.ciren.cl/handle/123456789/6869 Accessed on: 13 Feb. 2020.

[30] Análisis de la Oferta Hídrica del Salar de Atacama, Informe Técnico SDT No339. Dirección General de Aguas. Ministerio de Obras Públicas. Gobierno de Chile, 2013.

[31] CODEFF, Data research on lithium within the REdUSE Project Partners Countries, 2011. www.reduse.org/en/blog/lithium-extraction-chilean-north.

[32] Bolados Garcia, P., Los conflictos etnoambientales de "Pampa Colorada" y "el Tatio" en el Salar de Atacama, norte de Chile. Procesos étnicos en un contexto minero y turístico transnacional. Estudios atacamenos, 48, 2014. http://dx.doi.org/10.4067/S0718-10432014000200015.

[33] Gundermann, H. \& Göbel, B., Comunidades indígenas, empresas del litio y sus relaciones en el Salar de Atacama. Chungara, 50(3), 2018. http://dx.doi.org/10.4067/S0717-73562018005001602.

[34] CODEFF. Extractivismo del litio amenaza la vida y el agua en San Pedro de Atacama, 2018. www.codeff.cl/extractivismo-del-litio-amenaza-la-vida-y-el-agua-en-sanpedro-de-atacama/ Accessed on: 15 May 2020.

[35] Danwash, Chile: Explotación de litio deja sin agua a pobladores. Deutsche Welle. Alemania, 2020. www.dw.com/es/chile-explotaci\%C3\%B3n-de-litio-deja-sin-agua-apobladores/a-52165228. Accessed on: 20 May 2020.

[36] DFZ-2013-1006-II-RCA-IA., Informe de Fiscalización Ambiental a SQM Salar S.A., 2013. http://snifa.sma.gob.cl/v2/Fiscalizacion/Ficha/4040396. Accessed on: 13 Feb. 2020.

[37] DFZ-2014-26-II-RCA-IA., Informe de Fiscalización Ambiental a SQM Salar S.A., 2014. http://snifa.sma.gob.cl/v2/Fiscalizacion/Ficha/1001050. Accessed on: 13 Feb. 2020.

[38] DFZ-2015-43-II-RCA-IA., Informe de Fiscalización Ambiental a SQM Salar S.A., 2015. http://snifa.sma.gob.cl/v2/Fiscalizacion/Ficha/1001955. Accessed on: 13 Feb. 2020.

[39] DFZ-2016-2826-II-RCA-IA., Informe de Fiscalización Ambiental a SQM Salar S.A., 2016. http://snifa.sma.gob.cl/v2/Fiscalizacion/Ficha/1004860. Accessed on: 13 Feb. 2020. 
[40] Liu,W., Datu, B., Agusdinata, D. \& Myint, S., Spatiotemporal patterns of lithium mining and environmental degradation in the Atacama Salt Flat, Chile. International Journal of Applied Earth Observation and Geoinformation, 80, pp. 145-156, 2019. https://doi.org/10.1016/j.jag.2019.04.016. Accessed on: 15 Dec. 2019.

[41] Diaz, F.P. et al., Multiscale climate change impacts on plant diversity in the Atacama desert. Global Change Biology, 25(5), pp. 1-13, 2019.

https://doi.org/10.1111/gcb.14583.

[42] Business \& Human Right Resources Centre, Chile: Experta alerta sobre riesgos de agotamiento del agua por extracción de litio en salar de Atacama en nuevo proyecto de Wealth Minerals, 2019. www.business-humanrights.org/es/chile-experta-alertasobre-riesgos-de-agotamiento-del-agua-por-extracci\% $\mathrm{C} 3 \% \mathrm{~B} 3 n$-de-litio-en-salar-deatacama-en-nuevo-proyecto-de-wealth-minerals. Accessed on: 15 May 2020.

[43] Cambios y Mejoras de la Operación Minera en el Salar de Atacama. Declaración de Impacto Ambiental, Resumen Ejecutivo, Igsa Consultores, 2005.

http://seia.sea.gob.cl/expediente/expedientesEvaluacion.php?id_expediente $=1040282$ \&idExpediente=1040282. Accessed on: 13 Feb. 2020.

[44] Cambios y mejoras de la operación minera en el Salar de Atacama. Estudio de Impacto Ambiental, Empresa SQM. Resolución de Calificación Ambiental 0226, 2005. https://seia.sea.gob.cl/archivos/EIA/2013102201/EIA_1040282_Descripcion_del_pro yecto.pdf. Accessed on: 13 Feb. 2020.

[45] Chile sustentable, Presentan denuncia contra SQM y Escondida por daños en salar, 2016. www.chilesustentable.net/presentan-denuncia-contra-sqm-y-escondida-pordanos-en-salar/. Accessed on: 15 May 2020.

[46] Estudio de modelos hidrogeológicos conceptuales integrados, para los salares de Atacama, Maricunga y Pedernales. Etapa III. Informe Final. Modelo Hidrogeológico Consolidado Cuenca Salar de Atacama. Comité de Minería No Metálica CORFO. Santiago de Chile, p. 368, 2018.

[47] Göbel, B., La minería del litio en la Puna de Atacama: interdependencias transregionales y disputas locales. Iberoamericana, 13(49), pp. 135-149, 2013. www.jstor.org/stable/24369447. Accessed on: 15 May 2020

[48] Democracy Center Special Report. Bolivia and its lithium: can the "Gold of the 21st Century" help lift a nation out of poverty?, 2010. www.ifg.org/pdf/DClithium fullreportenglish.pdf. Accessed on: 15 May 2020.

[49] Mardones, L., Características isotópicas de las aguas subterráneas entre los paralelos $21^{\circ}$ y $24^{\circ}$ latitud sur, con énfasis en el Salar de Ascotán. Coloquio Internacional: El Recurso Agua en los Andes, Orstom - Universidad Católica del Norte, Antofagasta, 1997.

[50] Puente, F. \& Argento, M., Conflictos territoriales y construcción identitaria en los salares del noroeste argentino. En Geopolítica del Litio. Industria, Ciencia y Energía en Argentina. Bruno Fornillo (coordinador). Editorial El Colectivo. Buenos Aires. Argentina, pp. 123-166, 2015.

[51] Jerez, B., Impacto socioambiental de la extracción de litio en las cuencas de los salares altoandinos del cono sur. Brot für die Welt: Berlin, p. 55, 2018. www.ocmal.org/wp-content/uploads/2018/08/Impacto-Sociambiental-Litio.pdf. Accessed on: 10 Jun. 2019. 
[52] Marchegiani, P., Höglund Hellgren, J. \& Gómez, L., Extracción de litio en Argentina: un estudio de caso sobre los impactos sociales y ambientales. Fundación Ambiente y Recursos Naturales. Argentina. p. 53, 2019.

https://farn.org.ar/wp-content/uploads/2019/05/DOC_LITIO_ESPA\%C3\%91OL.pdf. Accessed on: 15 May 2020.

[53] Antecedentes para una Política Pública en Minerales Estratégicos: Litio. Santiago de Chile. COCHILCO, p. 46. Reg. Propiedad Intelectual (C) $\mathrm{N}^{\circ}$ 184.825, 2009. https://es.scribd.com/document/267816664/Antecedentes-para-una-Politica-Publicaen-Minerales-Estrategicos-Litio-COCHILCO. Accessed on: 15 May 2020.

[54] Fernández, R. \& Arriaza, S., Lessons from the failures of the Chilean extractivism model. Revista chilena de economía y sociedad, 11(2), pp. 39-49, 2017.

[55] CORFO. Modificación de contratos al Estado de Chile con Albemarle y SQM. CORFO-Ministerio de Chile, p. 23, 2018. 